\title{
EFL STUDENTS' AWARENESS AND ATTITUDES ON ENVIRONMENTAL ISSUES AND ITS EDUCATIONAL SOLUTION
}

\author{
Akhmad Fauzan \\ University of Palangka Raya \\ fauzanakhmad@yahoo.com
}

\begin{abstract}
The purpose of this paper is to illustrate the attitudes and awareness of secondary school students in Central Kalimantan towards environmental issues and to propose a framework to raise or improve those attitudes and awareness. The environmental issues covered in this paper are related to forest, bush, and peat land fires. The paper elaborates the secondary school students' attitudes and awareness obtained from questionnaires which were distributed to 12 Regencies and 1 City in Central Kalimantan. The findings in this paper show that most of the samples of secondary school students have insufficient knowledge about environmental issues and how to overcome the problems. Most of them did not take any action to prevent environmental destruction though they have expectation that their surroundings will be better in the future. Based on the findings, there are practical implications in attempts to minimize the problems which are happening annually in relation to the environment, particularly, peat land fires. There should be learning materials at school that can add to the knowledge of the students towards environment conservation. Schools have a major role to play because students are bound to follow formal education thus it fills the gap between students' knowledge and environmental problems.
\end{abstract}

Keywords: Attitude, Awareness, Environmental issues, English learning materials

In conclusion, this classroom activity was relatively successful to scaffold students mainly on reading comprehension, oral communication as well as raising grammatical awareness. The strategy was also successful to elevate students' motivation to get involved in discussion session, they were no longer reluctant to speak because the idea had already in their mind via clues from questions. Their reading comprehension have also improved due to making questions and discussion. Thus, "utilizing" students' mind is a key feature to dig up their critical thinking and creativity that lead them to be independent learners. It has been an annual issue in Kalimantan, especially in Central Kalimantan, that during the dry season there will be forest and bush fires that result in peat land fire. Central Kalimantan has widespread peat land which is approximately 4.34 million hectares in area (Najiyati et al., 2005a), which means there is a high susceptibility towards such problems every year. Those problems directly impact the community who live in the province, particularly in the areas that are vulnerable to fire. Further, peat land fires are more dangerous and damaging compared to forest fires because the fires are under the ground and the rehabilitation of peat land requires big costs (Najiyati, et. al., 2005b).

Although society has been the victim of forest, bush, and peat land fires, not many of the individual member of society who take action as a response to the damage they experience. In his speech during the ceremony of managing 
forest, land, and yard fires, the Vice Governor of Central Kalimantan called on society to actively manage the environment to protect them from fires (Sriyono, 2012). To people living in cities, they may not burn the forest or bush yet they are subject to the effects of it, like smoke which can harm their health and disrupt mobility. For those who live on the outskirts of towns, where the burning usually happens, they may directly experience the impact of fires but they do not take any action because they are sure that such mishap will end on their own.

In order to provide evidence of the actions taken by the general population when the forest, bush and peat land fires take place, then questionnaires were administered to senior high school students in Central Kalimantan because they are regarded as representing the part of the community who are young, active, and educated. Therefore, to fill the gap between the need for environmental conservation and the youth's attitudes and awareness towards environmental problems, this paper investigates the secondary school students' knowledge and actions, and proposes a framework which may be of significant help to minimize the annual environmental destruction because of fires in Central Kalimantan.

\section{METHOD}

This paper applies both quantitative and qualitative methods. The instrument used was questionnaire and the result was analyzed quantitative and qualitatively. The questionnaire was designed to obtain information related to students' knowledge, attitude, and future expectation, as well as the English learning materials they study at school. It was used to find out to what extent the attitudes affected the actions performed by the students when forest, bush, and peat land fires happen. Moreover, it was intended to measure how deep their understanding of preventive action was and their knowledge of their environment. The items comprised open ended questions and close ended questions with alternative answers.
The following table shows the elaboration of the questions.

\section{Table 1. Items in Questionnaire}

\begin{tabular}{|c|c|}
\hline Content of Questions & $\begin{array}{c}\text { Number } \\
\text { of Items }\end{array}$ \\
\hline Formal and informal environmental education & 6 \\
\hline $\begin{array}{c}\text { Students' knowledge on the environment: peat land } \\
\text { and its characteristics }\end{array}$ & 6 \\
\hline $\begin{array}{c}\text { Peat land fires: the action, the causes, the impact, the } \\
\text { rehabilitation, and future expectation }\end{array}$ & 8 \\
\hline $\begin{array}{c}\text { Bush and forest fires: the action, the causes, the } \\
\text { impact, the rehabilitation, and future expectation }\end{array}$ & 8 \\
\hline English learning materials & 2 \\
\hline Total & 30 \\
\hline
\end{tabular}

This questionnaire was then distributed to twelve regencies (Kabupaten Kotawaringin Barat, Lamandau, Kotawaringin Timur, Katingan, Seruyan, Kapuas, Pulang Pisau, Gunung Mas, Barito Utara, Murung Raya, Barito Selatan, Barito Timur) and one city (Kota Palangka Raya) in Central Kalimantan. Random sampling was applied in deciding the respondents. There were 122 students who became the sample for this paper consisting of 88 female students and 34 male students. The students were at twelfth grade level in order to get the whole depiction of their learning during their threeyears at school.

\section{FINDINGS AND DISCUSSION \\ Students' Attitude and Awareness}

In the questions asking the secondary school students about 'formal and informal environmental education', there were $71 \%$ students who admitted that they have Ecology as a local content subject in their schools. They study how to make compost out of leaves, about paper recycling, growing plants like vegetables and flowers, garbage processing, and soil types. At some schools, Ecology is studied at the tenth and eleventh grade, and some others until the twelfth grade. When the students were asked about informal education that they might get out of schools, $66 \%$ of students said that there were extension subjects in the neighborhood (penyuluhan) about the environment but more than a half of them admitted that they did not attend it.

In relation to information on students' 
knowledge of the environment, $94 \%$ of the students stated that they can recognize their surroundings in terms of the soil, flora, and fauna. Most students answered this question by giving a general description of their environment as peat land, bush, forest, farm land, and non-organic soil. The next question on the questionnaire asked about their knowledge of what peat land is and $85 \%$ of the students answered 'Yes'. They were able to mention the general characteristics of peat land, such as that it is made of dead plants, black/dark water, and easily burns during the dry season. The students could also identify the vegetation growing in the area. Though they could recognize the characteristics, about $76 \%$ of the students could not estimate the total area of peat land area in Central Kalimantan.

The next information sought through the questionnaire was about peat land fires regarding to students' actions in response to them, and the causes, the impact, the rehabilitation, and their future consequences. One question asking if the students have seen peat land fires in their neighborhood, $83 \%$ of the students chose the option 'Yes'. As they were asked if they took any action when the peat fires happened, 85\% responded ' $\mathrm{No}^{\prime}$. This relates to the next question, in which about half of them said they do not know what actions to take if they see peat fires. At about $90 \%$ students knew the causes of peat land fires as well as mentioning the impact of the fires and realized that management of environmental destruction caused by the fires is very urgent. However, $74 \%$ of them did not have any idea how to rehabilitate the peat land. Apart from the startling numbers above, 97\% responded that there will not be any environmental destruction in peat land in the future.

Further questions were asked about the bush and forest fires in the students' environment. This section began with question asking the students if they have seen the bush or forest fires in their area, to which $91 \%$ of the students responded they had although $75 \%$ admitted they did not take any action to stop the fires. Surprisingly, the number of students who knew what should be done when there was fire is relatively high at $72 \%$. About $84 \%$ of students knew the causes of bush or forest fires and a higher number, at $96 \%$, admitted that they knew the impact on their lives. About half of the respondents knew how to manage the bush or forest fire in their area and most of them $(82 \%)$ agreed that management of environmental destruction caused by bush or forest fires in their area is very urgent. In addition $99 \%$ of them have an expectation that there will not be any environmental or forest destruction in their area in the future.

The last piece of information to be obtained from the questionnaire is about the English subject at school. At senior high school level, in English students study various kinds of texts such as exposition (analytical and hortatory exposition), discussion, explanation, report, review, procedure, description, recount, anecdote, news item, narrative, and spoof. Those texts have been included in the curriculum and syllabus to support students to use applicable English in their daily lives. However, the texts they study in English are very general in terms of themes. The texts are not often related to or under the topic of peat land and allied issues such as peat land fires, destruction of peat land, bush/forest fires, land destruction because of bush/forest fires, destruction management in surroundings, and environmental conservation in peat land, environment and forest conservation. There were $22 \%$ students who agreed that some of the texts are related to those topics.

From the results of the questionnaire above, it can be concluded that senior high school students who became respondents in this paper have surface knowledge of peat land, bush or forest fires. The fires happen in the students' surrounding but most of them do not take any action to stop the fires. It is probably related to their low awareness of environmental issues even though they experience their impact. Further, they do not have strong motivations and 
attitudes towards environmental conservation yet they are willing to believe that it can be better in the future.

In order to respond to the findings above, a framework is proposed to minimize the annual peat land, bush or forest fires. The discussion is presented in the following section.

Proposed Framework

Based on the result of the questionnaire above, it is suggested that there should be a further analysis of the education process in the classroom. The analysis could be broken down into three aspects, namely the approach to teaching and learning, the media used to deliver knowledge in the classroom, and the learning materials.

Contextual Teaching and Learning (CTL)

It is already widely known in the teaching and learning of English, teachers apply approaches which can stimulate and actively involve students to use the language. One of many approaches used in the classrooms is Contextual Teaching and Learning (CTL). This approach is based upon notion that students may not be able to relate and employ what they learn in the schools to life out of schools. The learning materials given to students are theories for them to memorize, not to apply whenever they encounter real life. CTL is a learning concept in which to help teachers relate the learning materials to students' real world as well as to encourage them to make links between what is learned in the classroom to what they face outside the class. Through CTL, students are expected to be able to gain experiential learning, real world education, active learning, learner-centered instruction, and learning in context (Muslich, 2008) because CTL has elements of effective learning, namely constructivism, questioning, inquiry, learning community, modeling, reflection, and authentic assessment (Sismiati and Latief, 2012).

In relation to bush, forest, and peat land fires, then there should be teaching and learning activities in which to stimulate and motivate students to actively manage the environment. Those activities can be implemented in Ecology subject where students can practice extinguishing fires on and below the ground, or through Physics subject students can put into effect what they learn from theories about water stream or flow in order to soak dry peat land, or from Chemistry subject students practice to see the effect of cigarette butts to dry peat land which may contain combustible gases.

\section{Information and Communication Technology (ICT)}

ICT has been popular in the education field. The use of it is very beneficial not only for the teacher but also for the students. There have been many terms used to show the implementation of ICT in the classroom, like Computer Aided Instruction, Computer Assisted Learning, Computer Based Education, Web Based Learning, Web Based Instruction, amongst many others (Beatty, 2003). Those terms refer to one notion that the learning and/or teaching process is performed with the assistance of computers whether connected to an internet service provider or not.

The implementation of ICT at schools depends very much on the facilities provided. Technical supports like computer laboratories, internet connections, headsets, and electricity become major considerations in the use of ICT in the schools. In Central Kalimantan, the technical supports for schools located in the city and regency area varies. Some schools may have a computer laboratory but not insufficient electrical support. Some other schools may have a computer laboratory with or without internet connection. Some other schools may not have all those facilities. There is no complete data on the number of schools with complete or incomplete ICT facilities presented in this paper.

Apart from lack of facilities in reality, ICT actually plays an important role as medium of knowledge delivery in the classroom. Teaching and learning in Indonesia is based in student centered learning because teachers function as facilitators. In relation to raise students' 
awareness towards environmental issues, then, ICT could be further developed as a medium to transfer knowledge and materials about environment. The use of Microsoft Power Point as a presentation tool could provide interactive information. Teleconferencing could function as alternative way of experts attending from other regions to present materials which may be beyond the local teachers' expertise. Weblogs can be used by students to write or publish their writings related to the environment and it is expected that they will get responses from their friends or people who read their blogs. Social networking websites which are popular among students could also become media for sharing and posting information about recent events in the students' life.

\section{Environmental-themed English Learning Materials}

School-based curriculum, or known as Kurikulum Tingkat Satuan Pendidikan, is an operational curriculum which is developed by and implemented in every level of education in Indonesia. The development of school-based curriculum started and has been in place since 2007, and by refers to the Content Standard (Standar Isi) and the Graduate Competency Standards (Standar Kompetensi Lulusan) at the primary and secondary level (Badan Standar Nasional Pendidikan, 2006). The development of the curriculum is ceded to the school to fit the needs of the school itself. Therefore, teachers and school committees as well as experts from local universities are responsible in the development of the curriculum so its structure will be in accordance with the aspirations, situations, environmental condition, and community needs.

Since there is a chance to modify the curriculum based on the needs, then the materials should contribute to the students' lives. As an example, students who live on the seashore may have different needs to those who settle in mountainous areas. It is different as well for those who live in the peat land area. Therefore, the materials that students learn at schools should be adjusted to their environment. In order to address the environmental issues, particularly in peat land areas, then, the materials that students study should contain topics around problems in peat land areas, for example topics related to peat land, peat land fires, destruction of peat land, bush or forest fires, land destruction because of bush or forest fires, destruction management in the surroundings, environmental conservation in peat land, environment and forest conservation, and the impacts of fires, etc.

To make such topics applicable in the schools, it can be included in Ecology. However, not many schools in Central Kalimantan apply Ecology as local content in the curriculum. For the schools which do not apply Ecology, they can make use of English as the medium to deliver knowledge on environmental issues around peat land areas. English is regarded applicable because this subject contains materials on various texts, like exposition (analytical and hortatory exposition), discussion, explanation, report, review, procedure, description, recount, anecdote, news item, narrative, and spoof. At the tenth to twelfth grade, students study the genre texts in terms of the generic structures, social functions, and the linguistics features. However, the texts are under very general topics, such as tales, social events, personal experience, or living creatures. These topics indeed contribute to students' knowledge, but they do not contribute much on students' knowledge of environmental issues. Further, these general topics can be acquired by students through various sources inside and outside school hours.

The development of environmental-themed English learning materials is not a fanciful idea. It is an obvious solution that is easily implemented. Some ideas related to the development of genre texts to be environmental-themed can be described as follows. A procedure text is a text to describe how something is performed or accomplished through a sequence of actions or steps. Texts about steps about extinguishing 
fires on bush or forest or peat land can be a useful input for students when they encounter the fires. Description is a text that provides description of a person, animal, or particular thing or place. Texts describing peat land, or vegetative growing in peat land, or a particular ethnicity in a peat land area can be used to enrich students' knowledge of their surroundings.

A recount text is a text that tells the readers about the writer's experience. Texts containing someone's firsthand experience of weeks or months living in an area covered by smoke resulting from the forest and bush fires could be used to open students' minds about others' opinions towards the objection of the air pollution.

News items are a kind of text that informs the readers about events of the day which are considered newsworthy or important. Texts telling the impact of smoke on health, social life, or transportation could be used to encourage students to get to know the extent of the effects of bush, forest, or peat land fires.

Narrative text is a kind of text which tells stories or relates past events in order to entertain its readers. An interesting story about local people with the setting and plot which are familiar to students can be used to introduce the geographical and ethnographical conditions of a particular place and people in a peat land area.

Some of the kinds of texts above are only an

\section{REFERENCES}

Badan Standar Nasional Pendidikan. (2006). Panduan Penyusunan Kurikulum Tingkat Satuan Pendidikan Jenjang Pendidikan Dasar dan Menengah. Jakarta: Departemen Pendidikan Nasional.

Beatty, K. (2003). Teaching and Researching Computer-assisted Language Learning. Essex: Pearson Education Limited.

Najiyati, S., Asmana, A., \& Suryadiputra, I. N. N. (2005a). Pemberdayaan Masyarakat di Lahan Gambut. Bogor: Wetlands International - Indonesia Programme. exemplification of one way that those texts could be modified to carry environmental messages for the students. There are many other texts that students study at school, such as analytical and hortatory expositions, discussion, explanation, report, review, anecdote, and spoof, and these texts could also be modified to be brought into the classroom so they could enrich students' knowledge towards environmental issues.

\section{CONCLUSION}

Bush, forest, and peat land fires annually occur in Central Kalimantan so it requires many valuable contributions to overcome it, and one of them is through education sector. The implementation of School-based Curriculum (Kurikulum Tingkat Satuan Pendidikan) has given chance for teachers to develop teaching and learning materials based on the regional characteristics as well as using various approaches in teaching. The development of the materials and ICT may need not only the teachers' skills and abilities, but also the support from the national and regional Education Department, researchers, and university lecturers. With the strong supports, the raise of students' awareness on environment management can be accomplished. In the end, if all students are introduced and taught to the importance of environment, at least it will change the way they see their surroundings and it could minimize the destruction of environment in the future.

Najiyati, S., Muslihat, L., Suryadiputra, I. N. N. (2005b). Panduan Pengelolaan Lahan Gambut untuk Pertanian Berkelanjutan. Bogor:Wetlands International - Indonesia Programme.

Sismiati and Latief, M. A. (2012). Developing Instructional Materials on English Oral Communication For Nursing Schools. TEFLIN Journal, Vol 23, No. 1, Pp. 44-59. Available at http:/ /journal. teflin.org/index.php/teflin/article/ viewFile/291/238.

Sriyono, J. (2012). Perusahaan Asing Akan 
Dipidanakan. Available at http:// http:/ /www.suarakarya-online.com/ news.html?id=307590, accessed on July 19, 2012.
Muslich, M. (2008). KTSP Pembelajaran Berbasis Kompetensi dan Kontekstual. Jakarta: Bumi Aksara. 
